\title{
The Correlation Between Pre-treatment Fluorodeoxyglucose Positron Emission Tomography/Computed Tomography Parameters and Clinical Prognostic Factors in Pediatric Hodgkin Lymphoma
}

\author{
Pediatrik Hodgkin Lenfoma Hastalarında Tedavi Öncesi Florodeoksiglukoz Pozitron Emisyon \\ Tomografi/Bilgisayarlı Tomografı Parametreleri ve Klinik Prognostik Faktörler Arasındaki llişki
}

\author{
Ebru Tatcıl, Inci Uslu Binerl, Suna Emir2, Hikmet Gülşah Tanyıldız³, Özlem Özmenl, Engin Alagöz , Atila Gökçek5, \\ Gürses Şahin 3 \\ I Atatürk Chest Diseases and Thoracic Surgery Training and Research Hospital, Department of Nuclear Medicine, Ankara, Turkey \\ 2Ankara Children's Hematology Oncology Training and Research Hospital, Department of Pediatric Hematology Oncology, Ankara, Turkey \\ 3Dr. Sami Ulus Maternity and Children's Health and Diseases Training and Research Hospital, Department of Pediatric Oncology and \\ Hematology, Ankara, Turkey \\ ${ }^{4}$ Gülhane Training and Research Hospital, Department of Nuclear Medicine, Ankara, Turkey \\ ${ }^{5}$ Atatürk Chest Diseases and Thoracic Surgery Training and Research Hospital, Department of Radiology, Ankara, Turkey
}

\begin{abstract}
Objective: To compare standardized uptake values (SUV) derived from pre-treatment 18F-fluorodeoxyglucose (FDG) positron emission tomography/computed tomography (PET/CT) imaging and clinical prognostic factors in pediatric patients with Hodgkin lymphoma (HL).

Methods: Pre-treatment FDG PET/CT findings of 28 children with $\mathrm{HL}$ were evaluated in this retrospective study. Metabolic tumor volume (MTV), SUV max normalized by weight (SUV weight), lean body mass $\left(S U V_{\mathrm{lbm}}\right)$, body surface area $\left(S U V_{\text {bsa }}\right)$ and plasma glucose levels of tumors (SUV glucose $_{\text {) }}$ were calculated using pre-treatment FDG PET/CT scan images. These metabolic parameters were correlated with clinical factors [age, sex, number of lymph node groups, presence of splenic involvement, bulky mediastinal disease, Ann Arbor stage, serum white blood cell (WBC) count, erythrocyte sedimentation rate (ESR), serum albumin and hemoglobin levels].

Results: SUV bsa, SUV $V_{l b m}, S U V_{\text {weight }}, S_{\text {SU }}$ glucose and MTV were higher in patients with stage III-IV disease, bulky tumor and $\geq 3$ lymph node groups $(p<0.05)$. SUV $V_{\text {bsa }}$ and $S U V_{\text {glucose }}$ were higher in patients with splenic involvement $(p<0.05)$. There was no significant correlation between these metabolic parameters and sex, ESR, levels of albumin and WBC ( $p>0.05)$. SUV $\mathrm{SUV}_{\mathrm{lbm}}$ were higher in patients with anemia $(\mathrm{p}<0.05)$. Additionally, significant increases were detected in SUV weight, MTV, and $S U V_{\text {glucose }}$ with increasing age $\left(p=0.005, p=0.027\right.$, and $p=0.009$, respectively). SUV $V_{b s a}$ and $S U V_{\mid b m}$ had no significant correlation with age ( $p>0.05)$.

Conclusion: Metabolic parameters derived from pre-treatment FDG PET/CT may have an important role in predicting highrisk disease in patients with $\mathrm{HL}$. Also, $S U V_{\text {bsa }}$ and $S U V_{\mathrm{lbm}}$ may be better markers than $\mathrm{SUV}_{\text {weight }}$ in the quantitative evaluation of FDG PET/CT scans in pediatric patients.

Keywords: Fluorodeoxyglucose positron emission tomography/computed tomography, Hodgkin lymphoma, standardized uptake value, metabolic tumor volume
\end{abstract}

Address for Correspondence: Ebru Tatcı MD, Atatürk Chest Diseases and Thoracic Surgery Training and Research Hospital, Department of Nuclear Medicine, Ankara, Turkey Phone: +90 5059145361 E-mail: ebrualkandr@yahoo.com Received: 26.07.2016 Accepted: 24.10.2016 


\section{Öz}

Amaç: Hodgkin lenfoma (HL) tanısı konmuş çocuk hastalarda klinik prognostik faktörler ile tedavi öncesi 18F-florodeoksiglukoz (FDG) pozitron emisyon tomografi/bilgisayarlı tomografi (PET/BT) görüntülemeden elde edilen standart tutulum değerlerini (SUV) karşılaştırmaktır.

Yöntem: Bu retrospektif çalışmada HL tanılı 28 çocuk hastanın FDG PET/BT bulguları değerlendirildi. Metabolik tümör volümü (MTV), kiloya (SUV kilo), yağsız vücut kitlesine $\left(S U V_{l b m}\right)$, vücut yüzey alanına $\left(S U V_{\text {bsa }}\right)$ and plazma glukoz seviyesine $\left(S U V_{\text {glukoz }}\right)$ göre normalize edilmiş SUV maks değerleri tedavi öncesi FDG PET/CT görüntüleri kullanılarak hesaplandı. Bu metabolik parametrelerin klinik faktörler [yaş, cinsiyet, lenf nodu grup sayısı, dalak tutulumu, büyük mediastinal hastalık, Ann Arbor evreleme, serum lökosit sayımı (WBC), eritrosit sedimentasyon hızı (ESH), serum albumin ve hemoglobin seviyesi] ile ilişkisi araştırıldı.

Bulgular: SUV $\mathrm{bsa}, \mathrm{SUV}_{\mathrm{lbm}}, \mathrm{SUV}_{\mathrm{kilo}}, \mathrm{SUV}_{\text {glukoz }}$ ve MTV evre 3-4 hastalı̆̆ı, büyük tümörü ve $\geq 3$ lenf nodu grubu olan hastalarda daha yüksekti $(p<0,05)$. SUV $V_{\text {bsa }}$ ve $S U V_{\text {glukoz }}$ dalak tutulumu olan hastalarda daha fazlaydı $(p<0,05)$. Bu metabolik parametreler ile cinsiyet, ESR, albumin ve WBC seviyeleri arasında önemli bir ilişki yoktu $(p>0,05)$. SUV $V_{\text {bsa }}$ ve $S U V_{l b m}$ anemisi olan hastalarda daha yüksekti $(p<0,05)$. Ek olarak yaş arttıkça $S U V_{k i l o, ~}$ MTV ve $S U V_{\text {glukoz }}$ 'da önemli artış olduğu saptandı (sırasıyla; $p=0,005$, $p=0,027$ ve $p=0,009)$. $S U V_{b s a}$ ve $S U V_{\mid b m}$ ile yaş arasında önemli korelasyon yoktu $(p>0,05)$.

Sonuç: HL tanılı hastalarda tedavi öncesi FDG PET/BT'den elde edilen metabolik parametreler yüksek riskli hastalığı tahmin etmede önemli bir rol oynayabilir. Ayrıca, pediatrik hastalarda FDG PET/BT'nin kantitatif değerlendirilmesinde SUV $V_{\text {bsa }}$ ve $\mathrm{SUV}_{\mathrm{lbm}}$, SUV kilo' $^{\prime}$ dan daha iyi belirteç olabilir.

Anahtar kelimeler: Florodeoksiglukoz pozitron emisyon tomografi/bilgisayarlı tomografi, Hodgkin lenfoma, standart tutulum değeri, metabolik tümör volümü

\section{Introduction}

Currently, more than $80 \%$ of patients with Hodgkin lymphoma (HL) can be cured by contemporary treatment methods. The present major problem with $\mathrm{HL}$ is the long-term complications of treatment. Children who have been treated for $\mathrm{HL}$ have a higher risk of developing secondary tumors, cardiac events, and infections (1). Prognostic factors are considered during treatment planning to decrease the side effects and the likelihood of recurrence or treatment resistance (2). The most unfavorable prognostic factors according to the International Prognostic Score are stage 4 disease, age $\geq 45$ years, hemoglobin $<10.5 \mathrm{~g} / \mathrm{dl}$, albumin $<4.0 \mathrm{~g} / \mathrm{dl}$, white cell count $(\mathrm{WBC}) \geq 15,000 / \mu \mathrm{l}$, and lymphocyte level $<600 /$ $\mu \mathrm{l}$ or $<8 \%$, respectively. Also, presence of B symptoms, high erythrocyte sedimentation rate (ESR), male sex, higher number of involved nodal sites, and bulky-mass tumors are additional factors associated with an increased risk of relapse (3).

It has been reported in many studies that FDG PET-CT is a very useful imaging modality in the primary staging, restaging, assessment of treatment response and evaluation of residual masses of lymphomas $(4,5,6,7)$. Standardized uptake value (SUV) is used traditionally for the definition of metabolic activity in FDG PET imaging. The patient's body weight is usually employed as the body size measurement during the calculation of SUV. However, lean body mass or body surface area may be preferred for body size measurement by some authors. SUV is also affected by blood glucose level, post-injection uptake time, image resolution, image reconstruction parameters, and volume-of-interestdefinition $(8,9)$. Additionally, the maximum SUV $\left(S U V_{\max }\right)$ is only measured by the highest image pixel in the tumor regions and doesn't show the metabolic activity of the entire tumor. Metabolic tumor volume (MTV) is another FDG PET/CT parameter, which is the measurement of the tumor volume with increased metabolism. It has been reported that MTV could play an important role in predicting survival in various malignancies $(10,11)$. The purpose of this study was to evaluate the role of FDG-PET/CT in staging pediatric $\mathrm{HL}$, and to establish if the metabolic parameters of pre-treatment FDG PET/CT correlated with clinical prognostic factors in pediatric $\mathrm{HL}$ patients. If so, metabolic parameters of pre-treatment FDG PET/CT might have a role in predicting treatment failure. Additionally, we evaluated the correlation of age and metabolic parameters in pediatric patients.

\section{Materials and Methods}

\section{Patients}

Twenty-eight $\mathrm{HL}$ patients who underwent pre-treatment FDG PET/CT examinations between May 2009 and December 2014 were included in this retrospective study. Informed consent was waived due to the retrospective nature of the study. Patients older than 18 years were excluded. The study was approved by the Institutional Ethics Committee. The histologic classifications were established according to the standard WHO classification scheme (12). Results of bone marrow biopsy (BMB), levels of WBC, albumin and hemoglobin values and ESR were recorded. After completion of therapy, patients were 
followed by physical examination, laboratory analyses, chest radiographs, ultrasonography, CT or FDG PET/CT scans.

\section{Fluorodeoxyglucose Positron Emission Tomography/ Computed Tomography Imaging}

$\mathrm{PET} / \mathrm{CT}$ imaging was performed forty-five to sixty minutes after intravenous injection of 87.69-414.77 MBq (2.37$11.21 \mathrm{mCi}$ ) of FDG with a Siemens Biograph 6 HI-REZ integrated PET/CT scanner (Siemens Medical Solutions, Knoxville, TN, USA). All patients fasted for at least six hours before PET/CT imaging without water restriction. The blood glucose levels of patients were confirmed to be less than $180 \mathrm{mg} / \mathrm{dL}$ before FDG injection. Low-dose whole-body CT was used for attenuation correction. PET/ CT data were acquired from the top of the skull to the upper thigh.

\section{Fluorodeoxyglucose Positron Emission Tomography/ Computed Tomography Analysis}

\section{Visual Analyses}

Pre-treatment PET/CT images were retrospectively evaluated by two experienced nuclear medicine physicians and one radiologist. The number of lymph node groups was determined. A splenic FDG uptake greater than hepatic uptake was considered as splenic involvement. The marrow was considered as abnormal when the uptake was equal to or greater than that of the liver. Bulky disease was defined as presence of a lymph node mass greater than 0.33 of the maximum intrathoracic cavity width. The intensity of FDG activity within the bone marrow (BM) was evaluated visually. BMB results were used as the gold-standard for staging. The stage of lymphoma was assessed according to the Ann-Arbor classification (13).

\section{Semi-quantitative Analyses}

SUV $V_{\max }$ and MTV values were obtained from pre-treatment FDG PET/CT images for semi-quantitative evaluation. The SUV $V_{\max }$ corrected for body weight $\left(S U V_{\text {weight }}\right)$ was measured within the hottest tumor lesion according to the formula (14):

$$
\mathrm{SUV}_{\text {weight }}=\frac{\text { Tissue concentration }(\mathrm{MBq} / \mathrm{ml})}{\text { Injected dose }(\mathrm{MBq}) / \text { weight }(\mathrm{g})}
$$

The $S U V_{\max }$ normalized for lean body mass $\left(S U V_{l b m}\right)$, and body surface area $\left(S U V_{\text {bsa }}\right)$ were calculated using the following equations (14):

$$
\mathrm{SUV}_{\mathrm{lbm}}=\frac{\text { Tissue concentration }(\mathrm{MBq} / \mathrm{ml})}{\text { Injected dose }(\mathrm{MBq}) / \mathrm{lbm}(\mathrm{kg})}
$$

LBM (male) $(\mathrm{kg})=(1.1 \times$ weight $)(\mathrm{kg})-120$ [weight $(\mathrm{kg}) /$ height $(\mathrm{cm})]^{2}$

LBM (female) $(\mathrm{kg})=(1.07 \times$ weight $)(\mathrm{kg})-148$ [weight $(\mathrm{kg}) /$ height $(\mathrm{cm})]^{2}$

$$
\mathrm{SUV}_{\mathrm{bsa}}=\frac{\text { Tissue concentration }(\mathrm{MBq} / \mathrm{ml})}{\text { Injected dose }(\mathrm{MBq}) / \mathrm{BSA}\left(\mathrm{m}^{2}\right)}
$$

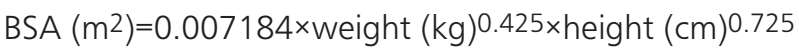

SUV values were also corrected for blood glucose level using an established formula, assuming a normal blood glucose level of $5.55 \mathrm{mmol} / \mathrm{L}(100 \mathrm{mg} / \mathrm{dL})(14)$ :

$$
S U V_{\text {glucose }}=\frac{S U V_{\text {max }} \times \text { blood glucose }(\mathrm{mmol} / \mathrm{L})}{5.55 \mathrm{mmol} / \mathrm{L}}
$$

MTV of each hypermetabolic tumor focus was automatically calculated by the software program and MTV of each tumor was summated. The threshold intensity value used in this study was $40 \%$ of maximal SUV of each tumor as validated in several previous studies $(15,16)$.

\section{Statistical Analyses}

The SPSS 20 software was used for statistical analysis. Comparisons of SUV levels (SUV weight, $S U V_{\text {bsa, }}, S U V_{1 b m}$, SUV $V_{\text {glucose, }}$ MTV) and clinical parameters (sex, number of lymph node groups, presence of splenic involvement, bulky disease, Ann Arbor stage, serum levels of albumin, WBC, ESR and hemoglobin) were performed using the independent test or Mann-Whitney $U$ test. All quantitative values are given as mean \pm standard deviation (SD). Pearson's correlation coefficients were used to evaluate the correlation between PET parameters and age. A statistically significant difference was defined as a $p$ value $<0.05$.

\section{Results \\ Patients}

The characteristics of the patients are presented in Table 1. A total of 28 patients with a mean age \pm SD of $9.39 \pm 4.2$ y (male/female: 17/11) were enrolled in this study. Eleven (39.3\%) patients had nodular sclerosis subtype and 15 (53.6\%) had mixed cellularity subtype. Histologic subtype remained unclassified in two patients. Of all 28 patients, 18 (64.2\%) had undergone BMB.

The laboratory findings of the patients are summarized in Table 2. Among all 28 patients, hemoglobin was $<10.5$ $\mathrm{g} / \mathrm{dl}$ in nine patients $(32.1 \%), W B C$ was $\geq 15000 / \mathrm{ml}$ in 11 patients (39.3\%), albumin was $<4 \mathrm{~g} / \mathrm{dl}$ in 16 patients 
(57.1\%), and ESR was $\geq 50 \mathrm{~mm} / \mathrm{hr}$ in 13 patients (46.4\%). All of the patients underwent three to six courses (612 cycles) of chemotherapy with or without radiation therapy after the initial PET/CT scanning. The mean \pm SD clinical follow-up period was $29 \pm 14$ months. All 28 patients were in remission at the last follow up, but one child died of infection. Recurrence was not detected in the follow-up.

\section{Fluorodeoxyglucose Positron Emission Tomography/ Computed Tomography Analyses}

\section{Visual Analyses}

Pre-treatment FDG PET/CT findings are summarized in Table 2. Bulky mediastinal disease was detected in 15 of the $28(53.5 \%)$ patients. While there were $<3$ lymph node groups in $28.6 \%$ of the 28 patients $(n=8), \geq 3$ lymph node groups were found in $71.4 \%(n=20)$. Splenic involvement was detected in $32.1 \%$ patients $(n=9)$. Eight patients had stage $1-2(28.6 \%)$ disease, and 20 patients had stage 3-4 (71.4\%) disease.

Increased diffuse BM FDG uptake in the axial skeleton was seen in 12/28 (42.8\%) patients. BMB was performed in 10 of these $12(83.3 \%)$ patients. Among ten patients with diffuse BM uptake, nine patients had negative BMB results (Figure 1). Only one patient showed positive lymphoma involvement in BMB. There was no increase in BM FDG uptake in 16 of $28(57.1 \%)$ patients. BMB was performed in seven of $16(43.7 \%)$ whose BMB result was negative. Additionally radioluceny and enlargement at the localizations of ischiopubic synchondrosis (IPS) were detected in 4 of the $28(14.2 \%)$ patients. Intense FDG uptakes were seen in these areas (SUV max range 1.17-3.10). These patients didn't suffer from any symptoms such as groin pain and restriction in the movement of the hip joint.

\begin{tabular}{ll} 
Table 1. Patient characteristics & \\
\hline Characteristics & $\mathbf{n}, \mathbf{( \% )}$ \\
\hline Sex M/F & $17(60.7)$ \\
Male & $11(39.2)$ \\
Female & $9.39 \pm 4.2$ \\
Age, y (mean \pm SD) & \\
Histological subtype & $11 / 28(39.3)$ \\
Nodular sclerosis & $15 / 28(53.6)$ \\
Mixed cellularity & $2 / 28(7.1)$ \\
Unclassified & $18 / 28(64.2)$ \\
Bone marrow biopsy & \\
Therapy & $12 / 28(42.8)$ \\
Chemotherapy & $16 / 28(57.1)$ \\
Chemoradiotherapy &
\end{tabular}

M: Male, F: Female, SD: Standard deviation
Since these focal FDG uptakes weren't identified in followup PET/CT scans, they were evaluated as the asymmetric ossification pattern of the IPS rather than malignant bone infiltration (Figure 2).

\section{Quantitative Analyses}

SUV bsar $_{\text {SU }}$ SUV $_{\text {Ibm, }}$ SUV $V_{\text {weight, }}$ SUV $_{\text {glucose, }}$ and MTV values were higher in patients with stage 3-4 disease, a bulky tumor, and $\geq 3$ lymph node groups $(p<0.05)$ (Table 2 ). $S U V_{\text {bsa }}$ and $S U V_{\text {glucose }}$ were higher in patients with splenic involvement $(p<0.05)$. There was no significant correlation between metabolic parameters and a) sex, b) ESR, c) albumin level, and d) WBC level ( $p>0.05$ ). Hemoglobin level lower than $10.5 \mathrm{~g} / \mathrm{dL}$ was associated with higher $S U V_{\text {bsa }}$ and SUV $V_{\text {lbm }}(p<0.05)$. While SUV $V_{b s a}$ and SUV $V_{l b m}(p>0.05)$ did not relate to age; SUV weight, MTV, and SUV glucose values were found to be significantly correlated with age $(p=0.005, p=0.027, p=0.009$ and $r=0.519, r=0.506$, $r=0.504$, respectively).

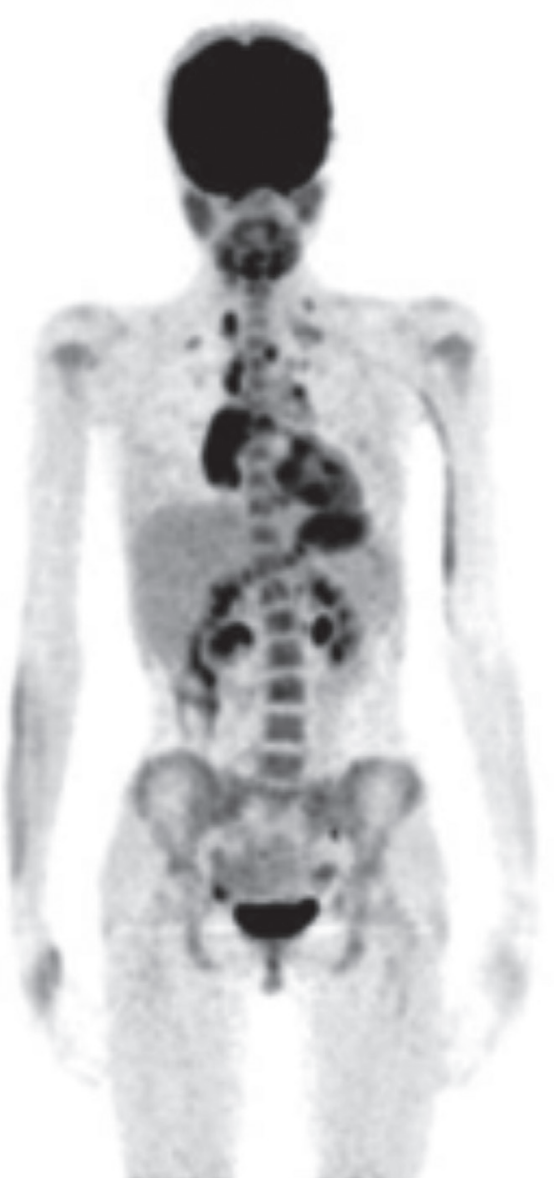

Figure 1. The maximum intensity projection image. Increased diffuse bone marrow fluorodeoxyglucose uptake in the axial system, and fluorodeoxyglucose uptake by supra-diaphragmatic lymph nodes are displayed. Bone marrow biopsy was negative 
Table 2. Fluorodeoxyglucose positron emission tomography/computed tomography parameters related to clinical prognostic factors

\begin{tabular}{|c|c|c|c|c|c|c|}
\hline Parameters & $\mathbf{n}$ & $\begin{array}{l}\text { SUV }_{\text {weight }} \\
\text { (mean } \pm S D \text { ) }\end{array}$ & $\begin{array}{l}\text { MTV } \\
(\text { mean } \pm S D)\end{array}$ & $\begin{array}{l}\text { SUV }_{\text {lbm }} \\
\text { (mean } \pm S D)\end{array}$ & $\begin{array}{l}S U V_{b s a} \\
\text { (mean } \pm S D)\end{array}$ & $\begin{array}{l}\text { SUV }_{\text {glucose }} \\
\text { (mean } \pm S D \text { ) }\end{array}$ \\
\hline \multicolumn{7}{|l|}{ Stage } \\
\hline $1-2$ & 8 & $4.8 \pm 2.9$ & $56.2 \pm 45.3$ & $1 \pm 0.4$ & $2 \pm 0.8$ & $5.8 \pm 2.1$ \\
\hline $3-4$ & 20 & $10.8 \pm 4.5$ & $377.7 \pm 301.9$ & $2 \pm 1.3$ & $3.9 \pm 1.3$ & $11.9 \pm 4.3$ \\
\hline$p$ value & & 0.002 & 0.012 & 0.006 & 0.002 & 0.001 \\
\hline \multicolumn{7}{|l|}{ Bulky tumor } \\
\hline Absent & 13 & $6.2 \pm 3.4$ & $162.2 \pm 206.4$ & $1.2 \pm 0.8$ & $2.4 \pm 1.2$ & $6.8 \pm 2.8$ \\
\hline Present & 15 & $11.6 \pm 4.7$ & $417.5 \pm 317.6$ & $2.2 \pm 1.3$ & $4.2 \pm 1.3$ & $12.7 \pm 4.3$ \\
\hline p value & & 0.002 & 0.032 & 0.034 & 0.001 & 0.001 \\
\hline \multicolumn{7}{|l|}{ NLG* } \\
\hline$<3$ & 8 & $5.6 \pm 3.2$ & $38.7 \pm 24.4$ & $1.1 \pm 0.4$ & $2.4 \pm 0.9$ & $6.3 \pm 1.9$ \\
\hline$\geq 3$ & 20 & $10.5 \pm 4.8$ & $360.9 \pm 299.4$ & $1.9 \pm 1.3$ & $3.7 \pm 1.5$ & $11.4 \pm 4.7$ \\
\hline p value & & 0.014 & 0.019 & 0.028 & 0.037 & 0.001 \\
\hline \multicolumn{7}{|c|}{ Splenic involvement } \\
\hline Absent & 19 & $7.9 \pm 3.8$ & $225 \pm 189.5$ & $1.6 \pm 1.2$ & $3 \pm 1.3$ & $8.6 \pm 3.9$ \\
\hline Present & 9 & $11.7 \pm 6.1$ & $455.8 \pm 403.7$ & $2.1 \pm 1.3$ & $4.2 \pm 1.6$ & $13.1 \pm 5.2$ \\
\hline$p$ value & & 0.054 & 0.106 & 0.327 & 0.044 & 0.023 \\
\hline \multicolumn{7}{|l|}{ Sex } \\
\hline Female & 11 & $8.1 \pm 3.9$ & $223 \pm 212.6$ & $1.6 \pm 1$ & $3.2 \pm 1.2$ & $8.5 \pm 2.9$ \\
\hline Male & 17 & $9.7 \pm 5.5$ & $341.1 \pm 325.4$ & $1.9 \pm 1.3$ & $3.4 \pm 1.7$ & $11.1 \pm 5.5$ \\
\hline p value & & 0.387 & 0.517 & 0.639 & 0.736 & 0.138 \\
\hline \multicolumn{7}{|c|}{ Leukocyte count } \\
\hline$<15000 / \mathrm{ml}$ & 17 & $8.4 \pm 4.2$ & $194.2 \pm 189.7$ & $1.5 \pm 1$ & $3 \pm 1.5$ & $9.5 \pm 4.6$ \\
\hline$\geq 15000 / \mathrm{ml}$ & 11 & $10.1 \pm 5.9$ & $438.7 \pm 353.8$ & $2.1 \pm 1.5$ & $3.9 \pm 1.3$ & $10.7 \pm 5$ \\
\hline p value & & 0.4 & 0.051 & 0.531 & 0.159 & 0.542 \\
\hline \multicolumn{7}{|c|}{ Hemoglobin (g/dl) } \\
\hline$\geq 10.5$ & 19 & $8.5 \pm 5.3$ & $291.5 \pm 327.4$ & $1.3 \pm 1$ & $2.9 \pm 1.4$ & $9.4 \pm 4.6$ \\
\hline$<10.5$ & 9 & $10.2 \pm 3.9$ & $361.8 \pm 221.6$ & $2.6 \pm 1.2$ & $4.3 \pm 1.3$ & $11.4 \pm 4.7$ \\
\hline$p$ value & & 0.21 & 0.165 & 0.012 & 0.028 & 0.313 \\
\hline \multicolumn{7}{|l|}{$\mathrm{ESR}(\mathrm{mm} / \mathrm{hr})$} \\
\hline$<50$ & 15 & $8.8 \pm 5.8$ & $318 \pm 344.7$ & $1.5 \pm 1.1$ & $3.2 \pm 1.4$ & $10 \pm 5.1$ \\
\hline$\geq 50$ & 13 & $9.4 \pm 3.8$ & $296.3 \pm 223.4$ & $1.9 \pm 1.3$ & $3.5 \pm 1.6$ & $10 \pm 4.4$ \\
\hline$p$ value & & 0.779 & 0.612 & 0.505 & 0.632 & 0.978 \\
\hline \multicolumn{7}{|c|}{ Albumin (g/dl) } \\
\hline$\geq 4$ & 12 & $9.1 \pm 6.5$ & $410.5 \pm 398.3$ & $1.3 \pm 1$ & $3.1 \pm 1.7$ & $9.6 \pm 5.5$ \\
\hline$<4$ & 16 & $9.1 \pm 3.5$ & $236.9 \pm 189.4$ & $2 \pm 1.3$ & $3.5 \pm 1.4$ & $10.3 \pm 4$ \\
\hline$p$ value & & 0.991 & 0.221 & 0.178 & 0.463 & 0.717 \\
\hline
\end{tabular}

*NLG: Number of lymph node groups; SUV weight $_{\text {: }}$ tandardized uptake value normalized by weight, SUV $\mathrm{lbm}_{\text {: }}$ Standardized uptake value normalized by lean body mass, SUV $\mathrm{bsa}$ : Standardized uptake value normalized by body surface area, SUV glucose $_{\text {: }}$ Standardized uptake value normalized by level of glucose, MTV: Metabolic tumor volume, SD: Standard deviation, ESR: Erythrocyte sedimentation rate 


\section{Discussion}

It was previously demonstrated in some studies in the literature that the amount of FDG accumulation is an important prognostic factor in various malignant tumors $(17,18)$. Ceriani et al. (19) reported that elevated MTV was significantly associated with worse progression-free and overall survival in patients with primary mediastinal (thymic) large B-cell lymphoma. Suh et al. (20) showed that pre-treatment FDG PET could predict treatment response and survival outcomes in patients with extranodal natural killer/T-cell lymphomas of the head and neck. Similarly, we identified a significant association between quantitative FDG uptake and clinical prognostic factors in pediatric patients with HL. The quantitative parameters were higher in patients with stage 3-4 disease, a bulky tumor, and $\geq 3$ lymph node groups $(p<0.05)$, which are the clinical parameters that reflect tumor burden. Intensity of tumor cells is one of the most important parameters to determine the efficacy of treatment in HL (21). High SUV $_{\max }$ and MTV can indicate poorer survival in patients with HL. Intensive therapy can be administered in these patients. However, in the presence of low FDG uptake, overtreatment can be avoided. The present study has several limitations. Cure was achieved in 27 of the 28 patients at the end of therapy and recurrence was not detected on follow-up. One child died of infection. So,
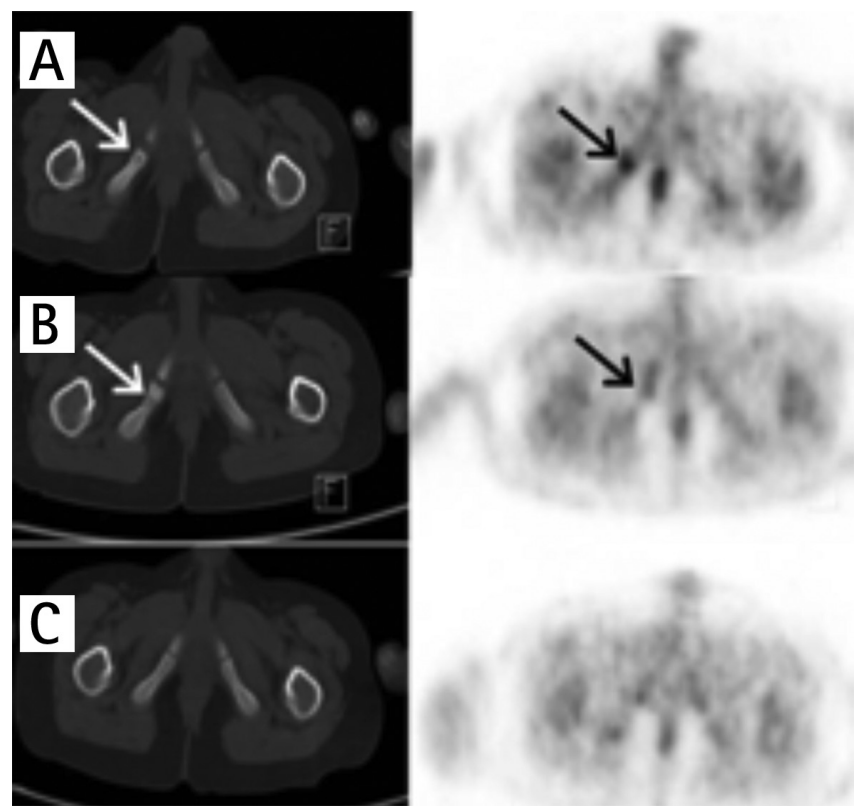

Figure 2. A) Axial positron emission tomography/computed tomography images of the pelvis in the bone window setting showed radiolucency and enlargement at the right ischium and increased focal fluorodeoxyglucose uptake at that area. B) Sclerosis at the same localization and decreased fluorodeoxyglucose uptake four months after therapy were seen. C) After 12 months of therapy no abnormal findings were detected on positron emission tomography/computed tomography scan (arrows) progression-free survival and overall survival couldn't be determined in this study.

Anemia, low albumin level, leukocytosis and high ESR level are particularly observed in advanced stage disease (3). $\mathrm{HD}$ is characterized by the presence of a low frequency of malignant cells known as Reed-Sternberg cells. The majority of the malignant tissues in HD constitutes a reactive cell infiltrate composed of variable proportions of lymphocytes, histiocytes, eosinophils, and plasma cells. Malignant Reed-Sternberg cells and reactive cells produce different cytokines. Close associations between elevation of cytokine levels in the plasma and presence of B symptoms, anemia, leukocytosis, high ESR and low serum albumin levels has been reported $(22,23)$. Our study results indicate that hemoglobin level lower than $10.5 \mathrm{~g} / \mathrm{dL}$ was associated with higher SUV $\mathrm{V}_{\mathrm{bsa}}$ and SUV $\mathrm{V}_{\mathrm{lbm}}$ $(p<0.05)$. Higher $S U V_{b s a}$ and SUBlbm may be related to higher tumor burden and higher plasma cytokine levels. However, we did not observe significant correlation between metabolic parameters and ESR, levels of albumin and WBC ( $p>0.05)$. Long-term follow-up studies with a larger group of patients may yield more satisfactory results.

The amountof SUV $V_{\text {weight }}$ changes was related to patient's body weight. However, some reports show that SUV $\mathrm{lbm}$ and $S U V_{\text {bsa }}$ are less dependent on body weight than SUV $V_{\text {weight }}(8,9)$. Concordant with these reports, our study showed that while SUV weight, MTV and SUV glucose increase with age $(p<0.05), S U V_{b s a}$ and $S U V_{l b m}$ did not significantly correlate with age $(p>0.05)$. Changes with age can reduce the importance of SUV weight, MTV and $\mathrm{SUV}_{\text {glucose }}$ values as markers to discriminate malignant tumors from benign ones in children. Also, these parameters can be misguiding in evaluating therapy response. $S U V_{\mathrm{lbm}}$ and $S U V_{\mathrm{bsa}}$ may be preferred in the primary diagnosis, staging and follow up of malignancies in the pediatric population (24).

A diffuse homogeneous BM FDG uptake generally reflects hyperplastic BM caused by severe anemia, use of granulocyte colony stimulating factors, or chemotherapy. However, infiltration of tumor cells can also cause increased diffuse BM FDG uptake. Authors suggest that $\mathrm{BMB}$ is the gold standard in the staging of HL (25). However, focal FDG uptake can be adequate in the diagnosis of bone or BM involvement in $\mathrm{HL}$ (13). Nevertheless, physiologic FDG uptake patterns mimicking bone metastasis such as IPS should be taken into consideration while evaluating PET/CT scans in the pediatric population (26).

\section{Conclusion}

Metabolic parameters derived from pre-treatment FDG PET/ CT scanning can be valuable in predicting high-risk disease in pediatric HL. Also, $S U V_{\text {bsa }}$ and $S U V_{\mathrm{lbm}}$ might be better 
markers than $S U V_{\text {weight }}$ in the quantitative evaluation of FDG PET/CT scans in pediatric patients. However, prospective studies with a larger group of patients are needed to obtain more reliable results.

\section{Ethics}

Ethics Committee Approval: The study were approved by the Atatürk Chest Diseases and Thoracic Surgery Training and Research Hospital of Local Ethics Committee. Informed Consent: Consent form was filled out by all participants. It was taken.

Peer-review: Externally peer-reviewed.

\section{Authorship Contributions}

Surgical and Medical Practices: Suna Emir, Hikmet Gülşah Tanyıldız, Gürses Şahin, Concept: Ebru Tatcı, Özlem Özmen, Design: Ebru Tatcl, Özlem Özmen, Data Collection or Processing: Ebru Tatcı, İnci Uslu Biner, Engin Alagöz, Suna Emir, Hikmet Gülşah Tanyıldız, Atila Gökçek, Analysis or Interpretation: Ebru Tatcı, Özlem Özmen, İnci Uslu Biner, Literature Search: Ebru Tatcı, Writing: Ebru Tatcı.

Conflict of Interest: Authors declared no conflict-of-interest. Financial Disclosure: The authors declared that this study received no financial support.

\section{References}

1. Santoro A, Bonadonna G, Valagussa P, Zucali R, Viviani S, Villani F, Pagnoni AM, Bonfante V, Musumeci R, Crippa F, et al. Long-term results of combined chemotherapy-radiotherapy approach in Hodgkin's disease: superiority of ABVD plus radiotherapy versus MOPP plus radiotherapy. J Clin Oncol 1987;5:27-37.

2. Carde P, Burgers JM, Henry-Amar M, Hayat M, Sizoo W, Van der Schuer en E, Monconduit M, Noordijk EM, Lustman-Marechal J, Tanguy A, et al. Clinical stages I and II Hodgkin's disease: a specifically tailored therapy according to prognostic factors. J Clin Oncol 1988;6:239-252.

3. Hasenclever D, Diehl V. A prognostic score for advanced Hodgkin's disease. International Prognostic Factors Project on Advanced Hodgkin's Disease. N Engl J Med 1998;339:1506-1514.

4. Tatsumi M, Miller JH, Wahl RL. 18F-FDG PET/CT in evaluating non-CNS pediatric malignancies. J Nucl Med 2007;48:19231931.

5. Depas G, De Barsy C, Jerusalem G, Hoyoux C, Dresse MF, Fassotte MF, Paquet N, Foidart J, Rigo P, Hustinx R. 18F-FDG PET in children with lymphomas. Eur J Nucl Med Mol Imaging 2005;32:31-38.

6. Newman JS, Francis IR, Kaminski MS, Wahl RL. Imaging of lymphoma with PET with 2-[F-18]-fluoro-2-deoxy-D-glucose: correlation with CT. Radiology 1994;190:111-116.

7. Stauss J, Franzius $C$, Pfluger $T$, Juergens $K U$, Biassoni $L$, Begent $J$, Kluge $\mathrm{R}$, Amthauer $\mathrm{H}$, Voelker T, Højgaard L, Barrington S, Hain S, Lynch T, Hahn K. Guidelines for 18F-FDG PET and PET-CT imaging in paediatric oncology. Eur J Nucl Med Mol Imaging 2008;35:15811588.

8. Adams MC, Turkington TG, Wilson JM, Wong TZ. A systematic review of the factors affecting accuracy of SUV measurements. AJR Am J Roentgenol 2010;195:310-320.

9. Kim CK, Gupta NC, Chandramouli B, Alavi A. Standardized uptake values of FDG: body surface area correction is preferable to body weight correction. J Nucl Med 1994;35:164-167.
10. Sager S, Asa S, Yilmaz M, Uslu L, Vatankulu B, Halaç M, Sönmezoglu $\mathrm{K}$, Kanmaz B.. Prognostic significance and predictive performance of volume-based parameters of F-18 FDG PET/CT in squamous cell head and neck cancers. J Cancer Res Ther 2014;10:922-926.

11. Park GC, Kim JS, Roh JL, Choi SH, Nam SY, Kim SY. Prognostic value of metabolic tumor volume measured by 18F-FDG PET/CT in advancedstage squamous cell carcinoma of the larynx and hypopharynx. Ann Oncol 2013;24:208-214.

12. Campo E, Swerdlow SH, Harris NL, Pileri S, Stein H, Jaffe ES. The 2008 WHO classification of lymphoid neoplasms and beyond: evolving concepts and practical applications. Blood 2011;117:50195032.

13. Cheson BD. Staging and response assessment in lymphomas: the new Lugano classification. Chin Clin Oncol 2015;4:5.

14. Paquet N, Albert A, Foidart J, Hustinx R. Within-patient variability of (18)F-FDG: standardized uptake values in normal tissues. J Nucl Med 2004;45:784-788.

15. Schwartz DL, Harris J, Yao M, Rosenthal DI, Opanowski A, Levering A, Ang KK, Trotti AM, Garden AS, Jones CU, Harari P, Foote R, Holland J, Zhang Q, Le QT. Metabolic tumor volume as a prognostic imaging-based biomarker for head-and-neck cancer: pilot results from Radiation Therapy Oncology Group protocol 0522. Int J Radiat Oncol Biol Phys 2015;91:721-729.

16. Son SH, Kim DH, Hong CM, Kim CY, Jeong SY, Lee SW, Lee J, Ahn BC. Prognostic implication of intratumoral metabolic heterogeneity in invasive ductal carcinoma of the breast. BMC Cancer 2014;14:585.

17. Berghmans T, Dusart $M$, Paesmans $M$, Hossein-Foucher $C$, Buvat I, Castaigne C, Scherpereel A, Mascaux C, Moreau M, Roelandts M, Alard S, Meert AP, Patz EF Jr, Lafitte JJ, Sculier JP. Primary tumor standardized uptake value (SUVmax) measured on fluorodeoxyglucose positron emission tomography (FDG-PET) is of prognostic value for survival in non-small cell lung cancer (NSCLC): a systematic review and meta-analysis (MA) by the European Lung Cancer Working Party for the IASLC Lung Cancer Staging Project. J Thorac Oncol 2008;3:6-12.

18. Ikenaga N, Otomo N, Toyofuku A, Ueda Y, Toyoda K, Hayash T, Nishikawa K, Tanaka M. Standardized uptake values for breast carcinomas assessed by fluorodeoxyglucose-positron emission tomography correlate with prognostic factors. Am Surg 2007:73:1151-1157.

19. Ceriani L, Martelli M, Zinzani PL, Ferreri AJ, Botto B, Stelitano C, Gotti M, Cabras MG, Rigacci L, Gargantini L, Merli F, Pinotti G, Mannina D, Luminari S, Stathis A, Russo E, Cavalli F, Giovanella L, Johnson PW, Zucca E. Utility of baseline 18FDG-PET/CT functional parameters in defining prognosis of primary mediastinal (thymic) large B-cell lymphoma. Blood 2015;126:950-956.

20. Suh C, Kang YK, Roh JL, Kim MR, Kim JS, Huh J, Lee JH, Jang YJ, Lee BJ. Prognostic value of tumor 18F-FDG uptake in patients with untreated extranodal natural killer/T-cell lymphomas of the head and neck. J Nucl Med 2008;49:1783-1789.

21. Specht L, Nordentoft AM, Cold S, Clausen NT, Nissen NI. Tumor burden as the most important prognostic factor in early stage Hodgkin's disease. Relations to other prognostic factors and implications for choice of treatment. Cancer 1988;61:1719-1727.

22. Niens $M$, Visser $L$, Nolte IM, van der Steege $G$, Diepstra $A$, Cordano P, Jarrett RF, Te Meerman GJ, Poppema S, van den Berg A. Serum chemokine levels in Hodgkin lymphoma patients: highly increased levels of CCL17 and CCL22. Br J Haematol 2008;140:527-536.

23. Salgami EV, Efstathiou SP, Vlachakis V, Sekara EV, Syrigos KN, Roussou PP. High pretreatment interleukin-10 is an independent predictor of poor failure-free survival in patients with Hodgkin's lymphoma. Haematologia (Budap). 2002;32:377-387.

24. Meier JM, Alavi A, Iruvuri $S$, Alzeair $S$, Parker $R$, Houseni $M$, Hernandez-Pampaloni M, Mong A, Torigian DA. Assessment of agerelated changes in abdominal organ structure and function with computed tomography and positron emission tomography. Semin Nucl Med 2007;37:154-172. 
25. Muzahir S, Mian M, Munir I, Khalid Nawaz M, Salman Faruqui Z, Aftab Mufti K, Bashir H, Uddin N, Siddiqui N, Maaz AU, Mahmood MT. Clinical utility of $18 \mathrm{~F} \mathrm{FDG-PET/CT} \mathrm{in} \mathrm{the} \mathrm{detection} \mathrm{of} \mathrm{bone} \mathrm{marrow}$ disease in Hodgkin's lymphoma. Br J Radiol 2012;85:e490-496.
26. Tsuji K, Tsuchida T, Kosaka N, Tanizawa A, Kimura H. Serial changes of (18)F-FDG PET/CT findings in ischiopubic synchondrosis: comparison with contrast-enhanced MRI. Hell J Nucl Med 2015;18:66-67. 